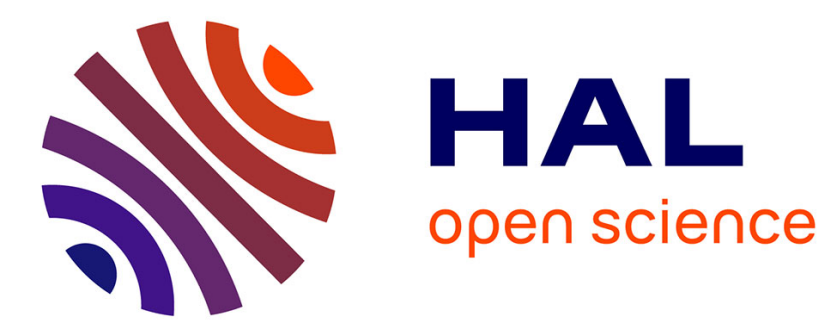

\title{
In vitro cell transformation induced by synthetic amorphous silica nanoparticles
}

\author{
Caroline Fontana, Anaïs Kirsch, Carole Seidel, Léa Marpeaux, Christian \\ Darne, Laurent Gaté, Aurélie Rémy, Yves Guichard
}

\section{To cite this version:}

Caroline Fontana, Anaïs Kirsch, Carole Seidel, Léa Marpeaux, Christian Darne, et al.. In vitro cell transformation induced by synthetic amorphous silica nanoparticles. Mutation Research - Genetic Toxicology and Environmental Mutagenesis, 2017, 823, pp.22 - 27. 10.1016/j.mrgentox.2017.08.002 . hal-01667424

\section{HAL Id: hal-01667424 https://hal.science/hal-01667424}

Submitted on 19 Dec 2017

HAL is a multi-disciplinary open access archive for the deposit and dissemination of scientific research documents, whether they are published or not. The documents may come from teaching and research institutions in France or abroad, or from public or private research centers.
L'archive ouverte pluridisciplinaire HAL, est destinée au dépôt et à la diffusion de documents scientifiques de niveau recherche, publiés ou non, émanant des établissements d'enseignement et de recherche français ou étrangers, des laboratoires publics ou privés.

\section{(1) (1) $\$$}

Distributed under a Creative Commons Attribution - NonCommercial - NoDerivatives 44.0 


\section{In vitro cell transformation induced by synthetic amorphous silica nanoparticles}

Caroline Fontana, Anaïs Kirsch, Carole Seidel, Léa Marpeaux, Christian Darne, Laurent Gaté, Aurélie Remy, Yves Guichard*

Institut National de Recherche et de Sécurité, Département de Toxicologie et de Biométrologie, 1 rue du Morvan, CS 60027, 54519 Vandœuvre Cedex, France

${ }^{*}$ Corresponding author:

E-mail address: yves.guichard@inrs.fr (Yves Guichard)

\section{Abstract}

Synthetic amorphous silica nanoparticles (SAS) are among the most widely produced and used nanomaterials, but little is known about their carcinogenic potential. This study aims to evaluate the ability of four different SAS, two precipitated, NM-200 and NM-201, and two pyrogenic, NM-202 and NM-203, to induce the transformation process. For this, we used the recently developed in vitro Bhas 42 cell transformation assay (CTA). The genome of the transgenic Bhas 42 cells contains several copies of the v-Ha-ras gene, making them particularly sensitive to tumor-promoter agents. The Bhas 42 CTA, which includes an initiation assay and a promotion assay, was validated in our laboratory using known soluble carcinogenic substances. Its suitability for particle-type substances was verified by using quartz Min-U-Sil 5 (Min-U-Sil) and diatomaceous earth (DE) microparticles. As expected given their known transforming properties, Min-U-Sil responded positively in the Bhas 42 CTA and DE responded negatively. Transformation assays were performed with SAS at concentrations ranging from $2 \mu \mathrm{g} / \mathrm{cm}^{2}$ to $80 \mu \mathrm{g} / \mathrm{cm}^{2}$. Results showed that all SAS have the capacity to induce transformed foci, interestingly only in the promotion assay, suggesting a mode of action similar to tumor-promoter substances. NM-203 exhibited transforming activity at a lower concentration than the other SAS. In conclusion, this study showed for the first time the transforming potential of different SAS, which act as tumor-promoter substances in the Bhas 42 model of cell transformation.

\section{Keywords:}

Synthetic amorphous silica; Nanomaterial; Cell transformation assay; Bhas 42 


\section{Introduction}

The worldwide production of synthetic amorphous silica nanoparticles (SAS) was estimated to be one million tons per year in 2006. These nanomaterials are used in many industrial applications such as chemistry, pharmaceuticals, cosmetics and foods [1]. Two main forms of SAS are produced in industries: precipitated SAS, obtained by acidification of sodium silicate under wet conditions; and pyrogenic SAS, obtained by hydrolysis of $\mathrm{SiCl}_{4}$ at high temperature [2]. Because of their amorphous crystal phase, SAS belong to the group of silica particles that are not classifiable as to their carcinogenicity to humans (Group 3), according to the International Agency for Research of Cancer (IARC) [3]. However, there is a lack of information about the cancer risk associated with SAS exposure. A full assessment of the hazards and risks for producers and users of these nanomaterials is therefore necessary.

Several in vitro and in vivo studies have reported cytotoxic and inflammatory effects induced by SAS of various origins and characteristics [2, 4]. Data on the genotoxic properties of SAS, mostly assessed by the comet assay for detecting DNA damage or by the micronucleus assay for chromosomal damage, are however less clear. Generally, positive responses in genotoxicity assays are reported more frequently in vitro [5-9] than in vivo [10-12]. However, in vitro results remain quite variable and depend on the physical and chemical characteristics of the SAS and the cell type used. On the other hand, little is known about the carcinogenic potential of SAS. To our knowledge, only one long-term carcinogenesis study in rats and one in vitro study using a cell transformation assay (CTA) have been published to date $[13,14]$.

The aim of the present study was to investigate the capacity of four different SAS (NM-200, NM-201, NM-202 and NM-203) to induce cell transformation. We therefore used the in vitro Bhas 42 CTA, which was recently the subject of a guidance document produced by the Organization for Economic Cooperation and Development (OECD) [15].

The principle of this assay is the following [15, 16]: the transgenic Bhas 42 cell line, established from Balb/c 3T3 cells, contains several copies of the v-Ha-ras gene. Similar to the parental Balb/c 3T3 cells, untransformed Bhas 42 cells grow to confluence forming a density-dependent contact-inhibited monolayer. However, after exposure to transforming stimuli, such cells become morphologically altered and form discrete colonies, referred to as transformed foci, atop the confluent monolayer. Interestingly, because they contain an activated oncogene, Bhas 42 cells can respond to tumor-promoter substances without undergoing preliminary treatment with an initiating substance, in contrast with other twostage cell transformation models. Furthermore, tumor-initiator substances can also transform Bhas 42 cells, for example, by inducing mutation of transformation-related genes (oncogenes and/or tumor suppressor genes). Based on this, the Bhas 42 CTA two transformation assays 
were performed in parallel (Figure 1). In the initiation assay, cells are seeded at low density and then treated once during the cell-growth phase (from Day 1 to Day 4). Cells are allowed to replicate and are then fixed and stained on Day 21 after plating for evaluation of the resulting transformed foci. These seeding and treatment conditions enable DNA damage and mutation fixation and favor the initiating activity of chemicals. In the promotion assay, cells are seeded at higher density. A first treatment is started at sub-confluence and is then repeated twice during a 10 day period (from Day 4 to Day 14). As in the initiation assay, the cells are then fixed and stained on Day 21 after plating. These conditions allow cell-to-cell communication and favor the promoting activity of chemicals. Thus, Bhas 42 cells can be used not only for the screening of chemicals with transforming activity but also for studying mechanisms of cell transformation.

In the present study, the suitability of the Bhas 42 CTA for particle-type substances was assessed using crystalline (quartz Min-U-Sil 5) and amorphous (diatomaceous earth) silica microparticles that have been previously evaluated for their transforming activity in the Syrian hamster embryonic (SHE) CTA $[17,18]$.

\section{Materials and methods}

\subsection{Particles}

SAS (NM-200, NM-201, NM-202, and NM-203) were obtained from the Joint Research Centre nanomaterials repository (Ispra, Italy). Min-U-Sil 5 (Min-U-Sil) was obtained from US Silica Co. (Berkeley). Diatomaceous earth (DE) was obtained from CECA (Paris, France). A thorough physical and chemical characterisation of SAS batches was conducted in a previous study [19] (Table 1). Min-U-Sil and DE batches have also been characterised previously [17].

\subsection{Cell culture}

Bhas 42 cells were established from the $\mathrm{v}$-Ha-ras-transfected BALB/c 3T3 cells by Sasaki et al. [20]. Frozen Bhas 42 cells at passage 19 were obtained from Harlan Laboratories (Rossdorf, Germany). In order to generate a large batch of cells from the same pool, the cells were cultivated in Eagle's minimum essential medium (Invitrogen, France), supplemented with $1 \%$ antibiotic (Streptomycin and Penicillin, Invitrogen) and $10 \%$ fetal bovine serum (FBS, Dutscher, France) (M10F) in a humidified $5 \% \mathrm{CO}_{2}$ incubator at $37{ }^{\circ} \mathrm{C}$. When the cultures reached about $70 \%$ confluence, they were subcultured using $0.25 \%$ trypsin (Invitrogen). Within two passages after thawing, the cultured cells were suspended at $5 \times 10^{5} \mathrm{cells} / \mathrm{mL}$ in 
fresh M10F containing 5\% dimethyl sulfoxide (DMSO, Sigma Aldrich, France), frozen in 0.5 $\mathrm{mL}$ volumes at $-80^{\circ} \mathrm{C}$ and stored in liquid nitrogen. All CTA performed in this study used this frozen batch of cells (passage 22), which was confirmed to be free from mycoplasma contamination. Dulbecco's modified Eagle's medium/Ham's F12 (Invitrogen) supplemented with $1 \%$ antibiotic and 5\% FBS (DF5F) was used for CTA. The batch of FBS used throughout this study was pre-screened to produce a minimal number of transformed foci in the Bhas 42 cells treated with the solvent control, DMSO, and a substantially elevated number of transformed foci in the cells treated with positive controls, 3-methylcholanthrene (MCA, Sigma Aldrich) at $1 \mu \mathrm{g} / \mathrm{mL}$ in the initiation assay or 12-O-tetradecanoylphorbol-13-acetate (TPA, Sigma Aldrich) at $0.05 \mu \mathrm{g} / \mathrm{mL}$ in the promotion assay [15].

\subsection{Cell treatment with particles}

Particle powders were mixed in a $20 \mathrm{~mL}$ glass vial with sterile de-ionized water. The concentration of particles was adjusted to $4.8 \mathrm{mg} / \mathrm{mL}$ for Min-U-Sil and $19.2 \mathrm{mg} / \mathrm{mL}$ for DE and SAS. The tube was placed in the cup horn of a $400 \mathrm{~W}$ Branson Sonifier S-450D (Branson Ultrasonics Corp, Danbury, CT) containing ice-cold water and then sonicated for 5 min at $10 \%$ amplitude. Particle size distribution was analysed by dynamic light scattering (DLS), using a Malvern Nano ZS (Malvern Inc., UK), immediately after preparation. For cell treatment, serial dilutions were prepared in sterile de-ionized water from the sonicated suspension. An appropriate volume of each of these preparations was diluted ten times for Min-U-Sil and fifty times for DE and SAS in DF5F (see section 2.4.). Final particle concentrations were expressed as mass per cell culture surface area. The concentrations were tested ranged from $5 \mu \mathrm{g} / \mathrm{cm}^{2}$ to $100 \mu \mathrm{g} / \mathrm{cm}^{2}$ for Min-U-Sil and from $2 \mu \mathrm{g} / \mathrm{cm}^{2}$ to 80 $\mu \mathrm{g} / \mathrm{cm}^{2}$ for DE and SAS.

\section{4. CTA and concurrent cell growth assays}

The CTA and concurrent cell growth assays in their six-well format were performed in accordance with the recommendations of the OECD [15]. The protocol is based on an initiation assay and a promotion assay and is illustrated in Figure 1. One tube of the frozen Bhas 42 cells (passage 22) was thawed and grown in M10F up to about $70 \%$ confluence and then subcultured in DF5F to reach about $70 \%$ confluence again. The cells were trypsinised and suspended either at a density of 2000 cells $/ \mathrm{ml}$ for seeding in $2 \mathrm{~mL}$ volume intended for the initiation assay (4000 cells/well, Day 0), or at a density of $7000 \mathrm{cells} / \mathrm{ml}$ for seeding in 2 $\mathrm{mL}$ volume intended for the promotion assay (14,000 cells/well, Day 0$)$. In the initiation assay, the cells were treated $24 \mathrm{~h}$ after seeding (Day 1) by the addition of a particle suspension, MCA solution $(1 \mathrm{mg} / \mathrm{mL}$ ), or the vehicles (sterile de-ionized water or DMSO). The treatment was continued for $72 \mathrm{~h}$ (Day 4). Next, all treatment media were removed, and the 
cells were post-cultivated in fresh medium until Day 21, receiving medium exchanges on Day 7, Day 10 and Day 14. In the promotion assay, the cells were cultured after seeding for four days without a medium exchange. In the regular CTA promotion assay (Figure 1), the culture medium was replaced on Day 4, Day 7, and Day 10 with a fresh medium containing particle suspensions, TPA solution $(0.05 \mathrm{mg} / \mathrm{ml})$ or the vehicles, and the treatment in the promotion phase was continued until Day 14 (for a total of 10 days). Observations of the cell cultures under a microscope showed that the majority of the tested particles were removed after each culture medium change. The cells were then cultured in the normal medium without the test chemical for one week until Day 21. A modified CTA promotion assay was also performed, in which cells were treated for three days only once, on Day 4. The cells were then postcultivated in fresh medium until Day 21, receiving medium exchanges on Day 7, Day 10 and Day 14. For all CTA, the cells were fixed with ethanol and stained with a $5 \%$ Giemsa solution (Fisher, France) on Day 21 and the transformed foci were evaluated according to the morphological criteria recommended by OECD [15]. For each experiment, the mean of the number of transformed foci per treatment group was determined from the six replicate wells. Statistical analysis was performed on results obtained from three independent experiments. CTA results were considered positive when there were two or more sequential concentrations that induced statistically significant increases in the number of transformed foci, and negative when no concentration showed a statistically significant increase in foci.

Cell growth assays were performed on Day 7. The colorimetric method (with crystal violet) recommended by OECD [15] could not be applied to cultures treated with nano- or microparticles because the presence of particle agglomerates in wells interfered with the measure of the optical density. The Trypan-Blue exclusion method was used as alternative method. In a single well dedicated to the growth assay, cells were recovered using $0.25 \%$ trypsin, stained with $0.1 \%$ Trypan-Blue solution (Sigma-Aldrich), and then counted under a microscope using a Nageotte hemocytometer. The relative cell growth of cultures treated with particles was calculated as follows:

Relative cell growth $(\%)=[($ Treatment $) /($ Control $)] \times 100$

where "Treatment" and "Control" refer to the number of viable cells counted in each treatment group and the vehicle control group, respectively. The concentration of particles used to assess their transformation activity was selected according to the results of two independent cell growth assays. These concentrations ranged from little or no toxicity to the highest acceptable level of toxicity (less than $20 \%$ survival compared to the vehicle control) [15]. The maximum particle concentration did not exceed 80 or $100 \mu \mathrm{g} / \mathrm{cm}^{2}$ in any case because the higher concentrations could have smothered cell cultures. 


\section{5. Statistical analysis}

Data are given as a mean \pm standard deviation (mean $\pm S D$ ). Statistical analyses were performed using Stata 14.0 software. A logarithmic transformation was applied to the data. The mixed linear regression model was used to test the "dose" fixed effect, including a random effect "experience". A multiple comparisons post hoc test (with Bonferroni correction) was applied to test the difference between control and different levels of doses. The statistical significant level was set to $5 \%$.

\section{Results}

\subsection{Transforming effect of MCA and TPA}

MCA $(1 \mu \mathrm{g} / \mathrm{mL})$ and TPA $(0.05 \mu \mathrm{g} / \mathrm{mL})$ were used as positive controls in all cell transformation assays performed with silica micro- and nanoparticles. In this study, the average number of transformed foci per well induced by MCA in initiation assays was $13.2 \pm$ 3.1 , versus $3.2 \pm 1.6$ transformed foci in the control $(0.1 \% \mathrm{DMSO})$, and the average number of transformed foci per well induced by TPA in promotion assays was $14.9 \pm 3.0$, versus 5.7 \pm 2.0 transformed foci in the control $(0.1 \% \mathrm{DMSO})$. Images of transformed foci obtained from CTA are shown in Figure S.1.

\section{2. Transforming effect of Min-U-Sil and DE}

Bhas 42 CTA results are shown in Figure 2 and photographs of representative CTA are shown in Figure S.2. Min-U-Sil induced a decrease in cell proliferation in a concentrationdependant manner in the initiation assay, with a 50\% inhibitory concentration (IC50) of around $20 \mu \mathrm{g} / \mathrm{cm}^{2}$. In contrast, the IC50 was not reached in the promotion assay. DE induced a decrease in cell proliferation in a concentration-dependant manner in the initiation assay with an IC50 of around $20 \mu \mathrm{g} / \mathrm{cm}^{2}$. In the promotion assay the IC50 was reached at 80 $\mu \mathrm{g} / \mathrm{cm}^{2}$.

In the initiation assay, Min-U-Sil treatment did not increase the number of transformed foci compared to the control. In the promotion conditions, however, Min-U-Sil treatment induced cell transformation, producing a bell-shaped response with a lowest observed adverse effect level (LOAEL) at $15 \mu \mathrm{g} / \mathrm{cm}^{2}$. In contrast, DE did not show any transforming activity at any of the concentrations tested in the initiation and promotion assays. On the contrary, the number of transformed foci decreased with the increase of particle concentrations.

\section{2. Transforming effect of SAS}


Bhas 42 CTA results are shown in Figure 3 and images of representative CTA are shown in Figure S2. With the exception of NM-200 treatment in the initiation assay, all SAS decreased cell proliferation in a concentration-dependant manner in both the initiation and promotion assay. In the initiation assay, the IC50 were around $40 \mu \mathrm{g} / \mathrm{cm}^{2}$ for NM-201 and NM-202, and around $20 \mu \mathrm{g} / \mathrm{cm}^{2}$ for NM-203. In the promotion assay, NM-202 and NM-203 showed the lowest IC50, at around $20 \mu \mathrm{g} / \mathrm{cm}^{2}$, while for NM-200 and NM-201, the IC50 was reached at $80 \mu \mathrm{g} / \mathrm{cm}^{2}$.

In the initiation assay, none of the SAS substantially increased the number of transformed foci compared to the control. In contrast, in the promotion assay, the four SAS significantly increased the number of transformed foci at at least two sequential concentrations. A bellshaped pattern of cell transformation was observed for all SAS. The LOAEL for cell transformation was observed at $2 \mu \mathrm{g} / \mathrm{cm}^{2}$ for NM-203, $10 \mu \mathrm{g} / \mathrm{cm}^{2}$ for NM-200 and NM-202 and $20 \mu \mathrm{g} / \mathrm{cm}^{2}$ for NM-201.

\section{3. Transforming effect of Min-U-Sil and NM-203 in the promotion assay performed with a} single treatment

The Transforming activity of Min-U-Sil and NM-203 were tested in a modified promotion assay, in which Bhas 42 cells were treated only on Day 4 (Figure 4). Under these experimental conditions, both treatments increased the average number of transformed foci compared to the control, but at a lower magnitude than under the conditions of the regular promotion assay (with three sets of treatment as shown in Figure 2 and 3). The LOAEL for cell transformation was observed at $20 \mu \mathrm{g} / \mathrm{cm}^{2}$ for Min-U-Sil and at $5 \mu \mathrm{g} / \mathrm{cm}^{2}$ for NM-203.

\section{Discussion}

Few data are available on the carcinogenic potential of SAS. To our knowledge, only one in vivo carcinogenesis study is reported in the literature. This study showed that five repeated intratracheal instillations of SAS in rats (3 $\mathrm{mg}$ per instillation) increased the incidence of lung tumours [13]. Interestingly, the characteristics of the SAS used in the study of [13] were very similar to NM-203. On the other hand, an in vitro cell transformation assay using Balb/c 3T3 cells showed no transforming activities for different SAS, including NM-200 and NM-203 [14].

In the present study, we used an in vitro model of cell transformation; the transgenic Bhas 42 cells that are particularly sensitive to tumor-promoter substances but also being sensitive to tumor-initiator substances [16]. A validation study covering 98 chemicals established an $84 \%$ specificity of the Bhas 42 CTA towards carcinogens and non-carcinogens [21]. 
In this study, the numbers of transformed foci obtained in control culture and in treated culture (MCA in the initiation assay and TPA in the promotion assay) were in agreement with those previously published [21, 22]. At the beginning of our study, the Bhas 42 CTA had not yet been tested with particle-type substances. Thus, we first submitted the assay to a known carcinogenic silica (Min-U-Sil) and to an amorphous silica (DE) so far not classified as carcinogenic [3, 23]. As expected, the Bhas 42 CTA was also able to detect the transforming activity of Min-U-Sil, but interestingly only in the promotion assay. DE treatment did not induce cell transformation, but decreased the number of transformed foci in the initiation and promotion assays. Other non-carcinogen chemicals such as L-ascorbic acid or caffeine have been found to lower the number of spontaneous transformed Bhas 42 foci [21].. Nevertheless, the fact that DE did not induce cell transformation in the Bhas 42 assay strongly supports its specificity towards particle-type substances.

In this study, we focused on the transforming potential of representatives of pyrogenic or precipitated SAS produced in industry. Interestingly, the same batches of SAS were evaluated for their toxicological effect in previous in vivo or in vitro studies. All four SAS were able to cause lung inflammation in rats by intratracheal instillation, but did not induce any DNA damage, neither in the lung nor in other secondary organs [11]. Similarly, none of them induced DNA damage in different tissues of rats exposed by gavage. However, a weak genotoxic effect was detected by the micronucleus assay in colon cells from rats treated by gavage with the two pyrogenic silica nanoparticles (NM-202 and NM-203) [12]. On the other hand, the four silica nanoparticles that we used were unable to induce in vitro micronuclei in human lymphocytes [8], and micronucleus assays were negative in Balb/c 3T3 exposed to NM-200 or NM-203 [14].

To our knowledge, our study is the first study to have shown the in vitro transforming activity of SAS. Cell proliferation assays indicated higher levels of cytotoxicity for the pyrogenic SAS (NM-202 and NM-203) compared to the precipitated SAS. Interestingly, Tavares et al. did not observe any cytotoxic activity after 30h treatment in human lymphocytes with any of the four SAS [8]. In our study, all SAS exhibited a bell-shaped-patterned transforming effect in the promotion assay. The decrease in cell transformation observed at the highest concentration of SAS can probably be explained by more pronounced growth inhibition after 21 days of culture, which is emphasised by the application of three sets of treatment. This type of pattern has also been observed for soluble transforming substances in the Bhas 42 CTA [15, 21]. Of the four SAS tested in the Bhas 42 CTA, NM-203, having induced cell transformation at the lowest concentration $\left(2 \mu \mathrm{g} / \mathrm{cm}^{2}\right)$, appeared to have the highest transforming potency. Rasmussen et al. reported that NM 203 particle aggregates possessed a particularly complex fractal structure that is associated with high production of oxygen species in 
aqueous solution [19]. This observation could explain the differential transforming effect of NM-203 compared to the other SAS.

Like with Min-U-Sil, the transforming effect of the four SAS was only detected under experimental conditions of promotion. On the other hand, the absence of any transforming effects of SAS in the initiation assay is consistent with the lack of genotoxicity of NM-200 or NM-203 previously shown in the Balb/c 3T3 cells [14]. Together, these observations suggest that the mode of action of SAS is similar to that of tumor-promoter agents. In order to test this hypothesis, we modified the promotion assay, performing only a single treatment of Min-U-Sil or NM-203 instead of the usual three sets of treatment. We observed that Min-U-Sil and NM203 were still capable of inducing cell transformation, but at a lower magnitude than in the original procedure. This demonstrated the importance of the role of cell confluence at the time of treatment with either type of silica particles; cell confluence was much higher under the promotion conditions than it was under the initiation conditions, where no transformation effect was detected. As the authors of the Bhas 42 CTA point out, cell confluence favours intercellular communication, which is recognised as a key factor of promotion mechanisms in carcinogenesis processes [15]. The experiment also showed that in the context of the original promotion assay, the first of the three treatments with Min-U-Sil or NM-203 was sufficient to trigger a cell transformation process. When a single treatment is performed, the promotion mechanism is probably maintained by the persistence of particle uptake throughout the assay.

Some studies have shown that high levels of SAS airborne particles can be found in situations of occupational exposure [24, 25]. However, based on an estimation derived from human tolerable levels, Murugadoss et al. concluded that relevant SAS concentrations for in vitro assays should not exceed $384 \mu \mathrm{g} / \mathrm{cm}^{2}$ [26]. Although it is generally difficult to extrapolate the in vitro dose to the in vivo status, SAS concentrations used in this study (ranging from 2 $\mu \mathrm{g} / \mathrm{cm}^{2}$ to $80 \mu \mathrm{g} / \mathrm{cm}^{2}$ ) could be considered as physiologically relevant.

In conclusion, this study has shown, for the first time, the transforming potential of different SAS. We employed a promising model of cell transformation, the Bhas 42 CTA, which was designed for the detection of tumor-promoter agents. Further studies are now needed to understand, at the molecular level, the mechanisms of promotion involved in the transforming effect of SAS, such as epigenetic events. 
Table 1 : Physical characteristics of silica particles used in this study

\begin{tabular}{|c|c|c|c|c|c|c|c|}
\hline \multirow[b]{2}{*}{ Silica $^{a}$} & \multirow[b]{2}{*}{ Origin } & \multirow[b]{2}{*}{ Main phase } & \multirow[b]{2}{*}{$\begin{array}{l}\text { Primary } \\
\text { particle } \\
\text { size }^{b}\end{array}$} & \multirow[b]{2}{*}{$\begin{array}{l}\text { Impurities } \\
(w+\%)^{c}\end{array}$} & \multirow[b]{2}{*}{$\begin{array}{l}\text { BET SSA } \\
\left(\mathrm{m}^{2} / \mathrm{g}\right)^{d}\end{array}$} & \multicolumn{2}{|c|}{$\mathrm{DLS}^{\mathrm{e}}$} \\
\hline & & & & & & $\begin{array}{l}\text { Z-average in } \\
\text { Water }(\mathrm{nm})\end{array}$ & $\begin{array}{l}\text { Polydispersity } \\
\text { index }\end{array}$ \\
\hline NM-200 & Precipitated & Amorphous & $18.3 \pm 4.5 \mathrm{~nm}$ & $\mathrm{Al}(0.87) ; \mathrm{Na}(0.88) ; \mathrm{S}(0.46)$ & 189 & $N D^{f}$ & ND \\
\hline NM-201 & Precipitated & Amorphous & $18.0 \pm 1.0 \mathrm{~nm}$ & $\mathrm{Al}(0.74) ; \mathrm{Na}(0.44) ; \mathrm{S}(0.46)$ & 140 & $252.9 \pm 11.3$ & $0.583 \pm 0.019$ \\
\hline NM-202 & Pyrogenic & Amorphous & $17.7 \pm 2.5 \mathrm{~nm}$ & $\mathrm{Al}(0.45) ; \mathrm{Ca}(0.18)$ & 204 & $232.8 \pm 7.3$ & $0.441 \pm 0.012$ \\
\hline NM-203 & Pyrogenic & Amorphous & $24.7 \pm 17.7 \mathrm{~nm}$ & $\mathrm{Al}(0.43) ; \mathrm{S}(0.04)$ & 204 & $318.7 \pm 4.9$ & $0.423 \pm 0.026$ \\
\hline Min-U-Sil & Natural & Crystalline & $1.33 \pm 0.85 \mu \mathrm{m}$ & $\mathrm{Al}(0.16) ; \mathrm{Fe}(0.05) ; \mathrm{Ca}(0.04) ; \mathrm{Mg}(0.01)$ & 5 & $1385.7 \pm 377.0$ & $0.318 \pm 0.130$ \\
\hline DE & Natural & Amorphous & $1.35 \pm 1.48 \mu \mathrm{m}$ & $\mathrm{Al}(1.4) ; \mathrm{Fe}(1.3) ; \mathrm{Ca}(2.2) ; \mathrm{Ti}(0.3) ; \mathrm{Mg}(0.2)$ & 20 & ND & ND \\
\hline
\end{tabular}

${ }^{a}$ With the exception of DLS data, detailed physical and chemical characterizations are available in [19] for SAS and [17] for Min-U-Sil and DE.

${ }^{\mathrm{b}}$ Primary size was determined by transmission electron microscopy.

${ }^{\mathrm{C}}$ Impurities were determined by energy dispersive spectrometry for SAS and by inductively coupled plasma spectrometry for Min-U-Sil and DE.

${ }^{\mathrm{d}}$ The BET (Brunauer-Emmet-Teller) specific surface area (SSA) was determined by nitrogen adsorption.

eDynamic light scattering (DLS) was performed using a Nanozetasizer (Malvern). Samples were dispersed in water as described in the Materials and Methods section. Values represent the mean \pm standard deviation of three DLS analyses.

${ }^{f}$ Not determined, data obtained by DLS analysis did not meet the quality criteria. 


\section{Figures}

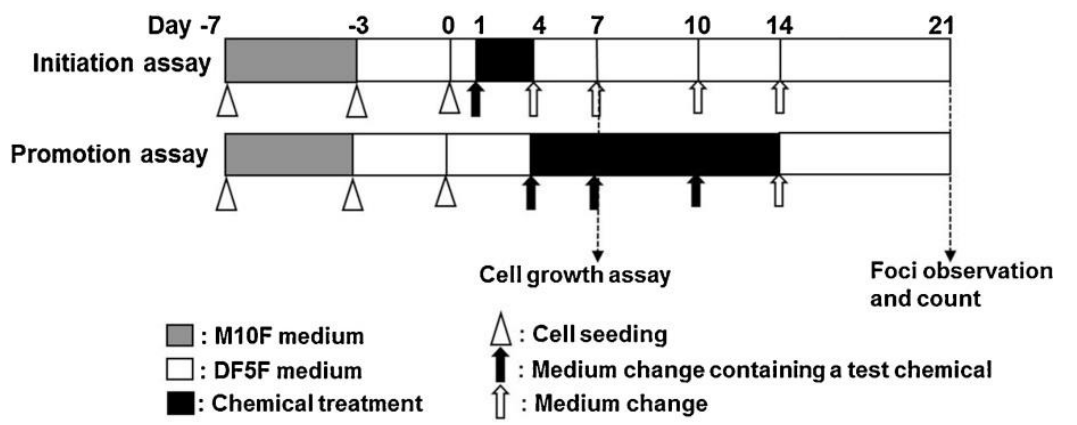

Figure 1: Schematic representation of the Bhas 42 cell transformation assay, which includes the initiation and the promotion assay. Cytotoxic effect was assessed by cell growth assays performed on Day 7. On Day 21, cells were fixed with ethanol and stained with Giemsa solution and transformed foci were analysed under a microscope.

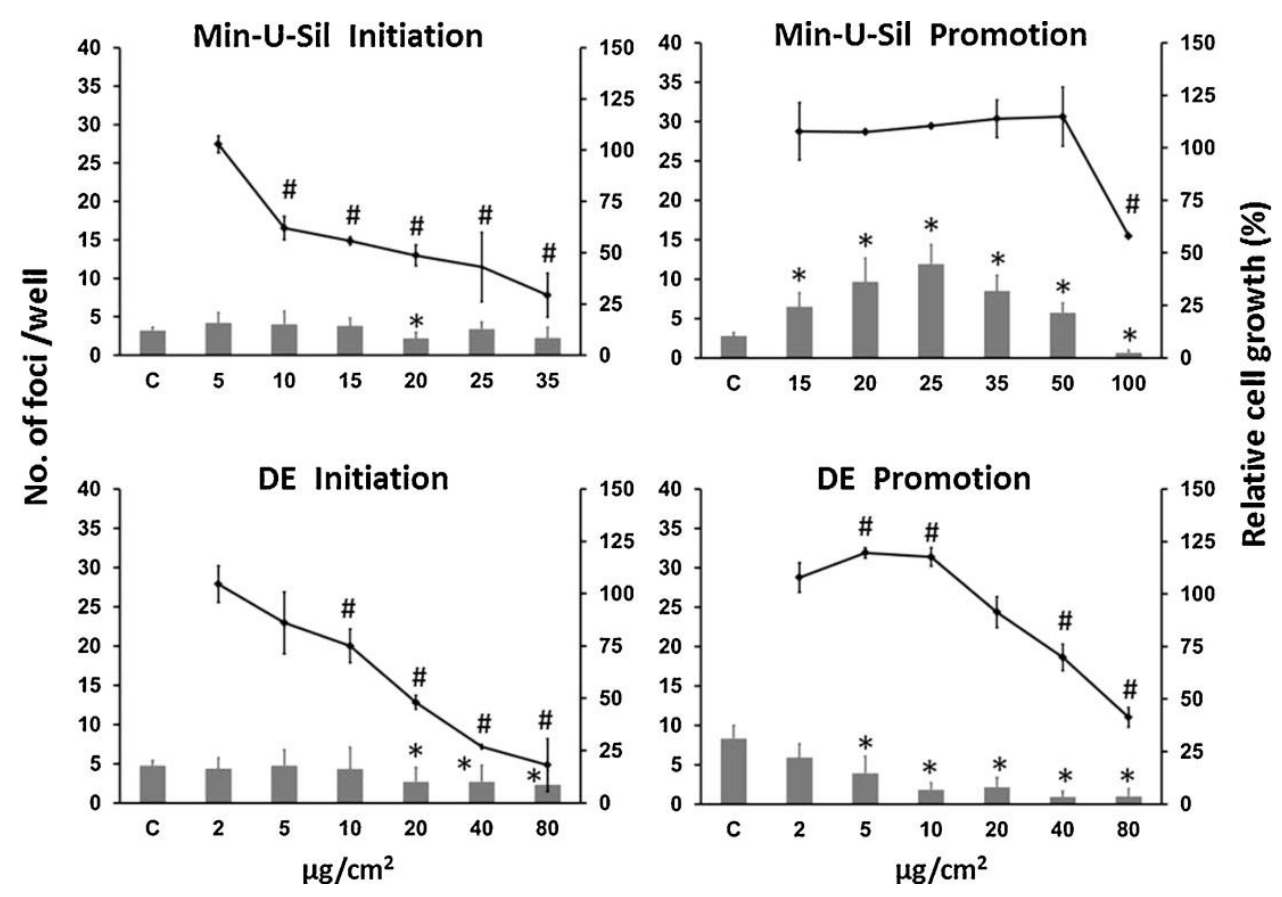

Figure 2: Results of initiation and promotion Bhas 42 CTA (histogram, $n=6,{ }^{*} p<0.05$ ) and cell growth assays (curve, $\# p<0.05$ ) on Min-U-Sil and diatomaceous earth (DE). C: control (treatment with $10 \% \mathrm{H}_{2} \mathrm{O}$ for Min-U-Sil or $2 \% \mathrm{H}_{2} \mathrm{O}$ for DE). Results are expressed as the mean \pm SD of three independent experiments for CTA or two independent experiments for cell growth assays. 

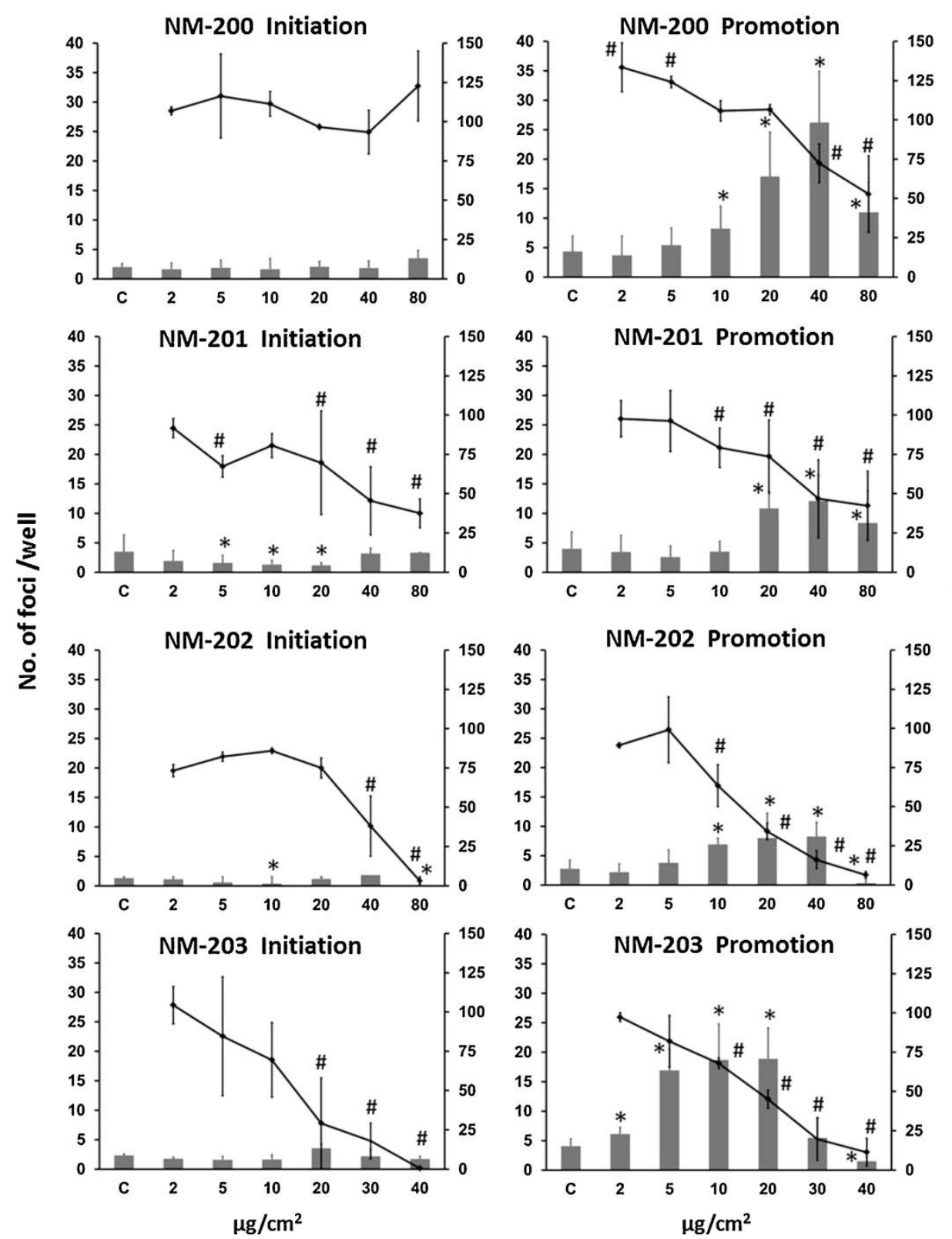

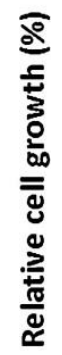

Figure 3: Results of initiation and promotion Bhas 42 CTA (histogram, $\mathrm{n}=6,{ }^{*} p<0.05$ ) and cell growth assays (curve, $\# p<0.05$ ) on SAS. C: control (treatment with $2 \% \mathrm{H}_{2} \mathrm{O}$ ). SAS: synthetic amorphous silica nanoparticles. Results are expressed as the mean \pm SD of three independent experiments for CTA or two independent experiments for cell growth assays. 

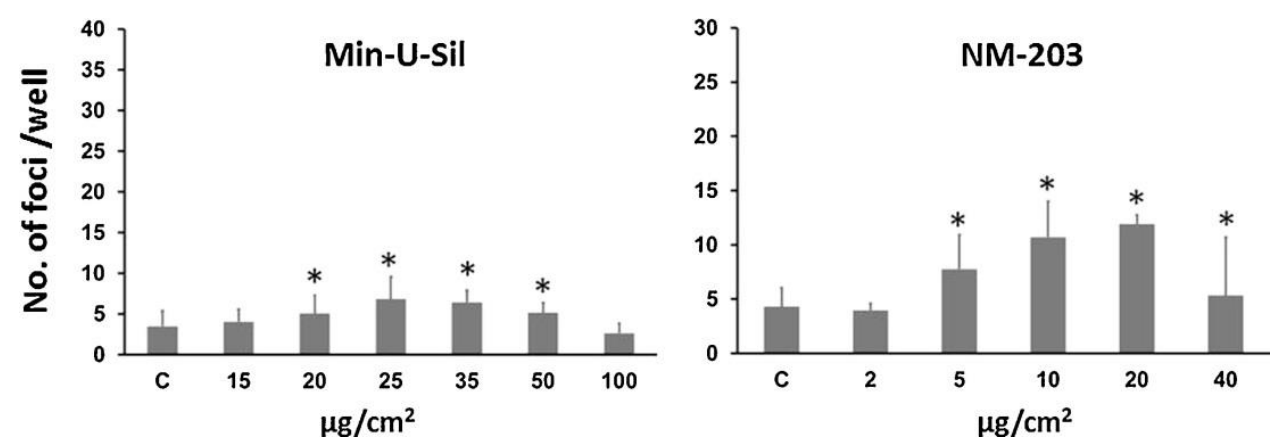

Figure 4: Results of the modified promotion Bhas 42 CTA (treatment on Day 4 only) (histogram, $n=6,{ }^{*} p<0.05$ ) on Min-U-Sil and NM203. C: control (treatment with $10 \% \mathrm{H}_{2} \mathrm{O}$ for Min-U-Sil or $2 \% \mathrm{H}_{2} \mathrm{O}$ for NM-203). Results are expressed as the mean \pm SD of three independent experiments for CTA.

Figures in Supplementary data.

\begin{tabular}{|c|c|c|c|}
\hline Treatment & $\begin{array}{c}\text { Control } \\
(0.1 \% \mathrm{DMSO})\end{array}$ & $\begin{array}{c}\mathrm{MCA} \\
(1 \mathrm{\mu g} / \mathrm{mL})\end{array}$ & $\begin{array}{c}\mathrm{TPA} \\
(0.05 \mu \mathrm{gg} / \mathrm{mL})\end{array}$ \\
\hline $\begin{array}{c}\text { Initiation } \\
\text { assay }\end{array}$ & & & \\
\hline $\begin{array}{c}\text { Promotion } \\
\text { assay }\end{array}$ & $\vdots$ & & \\
\hline
\end{tabular}

Figure S.1: Representative cell cultures obtained on Day 21 from CTA performed with 3methylcholanthrene (MCA) in the initiation assay or 12-O-tetradecanoylphorbol-13-acetate (TPA) in the promotion assay. Treatments with $0.1 \%$ dimethyl sulfoxide (DMSO) were used as the negative control.

\begin{tabular}{|c|c|c|c|c|c|c|c|}
\hline Treatment & $\begin{array}{c}\text { Control } \\
\left(2 \% \mathrm{H}_{2} \mathrm{O}\right)\end{array}$ & $\begin{array}{c}\mathrm{DE} \\
\left(20 \mu \mathrm{g} / \mathrm{cm}^{2}\right)\end{array}$ & $\begin{array}{c}\text { Min-U-Sil } \\
\left(25 \mu \mathrm{g} / \mathrm{cm}^{2}\right)\end{array}$ & $\begin{array}{c}\mathrm{NM}-200 \\
\left(40 \mu \mathrm{g} / \mathrm{cm}^{2}\right)\end{array}$ & $\begin{array}{c}\mathrm{NM}-201 \\
\left(40 \mu \mathrm{g} / \mathrm{cm}^{2}\right)\end{array}$ & $\begin{array}{c}\mathrm{NM}-202 \\
\left(20 \mu \mathrm{g} / \mathrm{cm}^{2}\right)\end{array}$ & $\begin{array}{c}\mathrm{NM}-203 \\
\left(20 \mathrm{\mu g} / \mathrm{cm}^{2}\right)\end{array}$ \\
\hline $\begin{array}{c}\text { Initiation } \\
\text { assay }\end{array}$ & & & & & & \\
\hline $\begin{array}{c}\text { Promotion } \\
\text { assay }\end{array}$ & & & & & & & \\
\hline
\end{tabular}

Figure S.2: Representative cell cultures obtained on Day 21 from CTA performed with DE, Min-U-Sil or SAS in the initiation assay and in the promotion assay. Treatments with $2 \% \mathrm{H}_{2} \mathrm{O}$ were used as negative controls in all CTA except for Min-U-Sil, for which the negative control was $10 \% \mathrm{H}_{2} \mathrm{O}$ (not shown). 


\section{References}

[1] ECETOC, ECETOC JACC REPORT, N51 Synthetic Amorphous Silica (Cas 7631-86-9), (2006) 1-237.

[2] C. Fruijtier-Polloth, The toxicological mode of action and the safety of synthetic amorphous silicaa nanostructured material, Toxicology, 294 (2012) 61-79.

[3] IARC, Silica, some silicates, coal dust and para-Aramid fibrils, IARC Monographs on the Evaluation of Carcinogenic Risks to Humans, 68 (1997) 1-506.

[4] D. Napierska, L.C. Thomassen, D. Lison, J.A. Martens, P.H. Hoet, The nanosilica hazard: another variable entity, Part Fibre Toxicol, 7 (2010) 39.

[5] C.A. Barnes, A. Elsaesser, J. Arkusz, A. Smok, J. Palus, A. Lesniak, A. Salvati, J.P. Hanrahan, W.H. Jong, E. Dziubaltowska, M. Stepnik, K. Rydzynski, G. McKerr, I. Lynch, K.A. Dawson, C.V. Howard, Reproducible comet assay of amorphous silica nanoparticles detects no genotoxicity, Nano letters, 8 (2008) 3069-3074.

[6] Q. Mu, N.S. Hondow, L. Krzeminski, A.P. Brown, L.J. Jeuken, M.N. Routledge, Mechanism of cellular uptake of genotoxic silica nanoparticles, Part Fibre Toxicol, 9 (2012) 29.

[7] K. Gerloff, C. Albrecht, A.W. Boots, I. Förster, R.P. Schins, Cytotoxicity and oxidative DNA damage by nanoparticles in human intestinal Caco-2 Cells, Nanotoxicology, 3 (2009) 355-364.

[8] A.M. Tavares, H. Louro, S. Antunes, S. Quarre, S. Simar, P.J. De Temmerman, E. Verleysen, J. Mast, K.A. Jensen, H. Norppa, F. Nesslany, M.J. Silva, Genotoxicity evaluation of nanosized titanium dioxide, synthetic amorphous silica and multi-walled carbon nanotubes in human lymphocytes, Toxicol In Vitro, 28 (2014) 60-69.

[9] Y. Guichard, C. Fontana, E. Chavinier, F. Terzetti, L. Gate, S. Binet, C. Darne, Cytotoxic and genotoxic evaluation of different synthetic amorphous silica nanomaterials in the V79 cell line, Toxicol Ind Health, (2015).

[10] C.J. Johnston, K.E. Driscoll, J.N. Finkelstein, R. Baggs, M.A. O'Reilly, J. Carter, R. Gelein, G. Oberdorster, Pulmonary chemokine and mutagenic responses in rats after subchronic inhalation of amorphous and crystalline silica, Toxicol Sci, 56 (2000) 405-413.

[11] Y. Guichard, M.A. Maire, S. Sebillaud, C. Fontana, C. Langlais, J.C. Micillino, C. Darne, J. Roszak, M. Stepnik, V. Fessard, S. Binet, L. Gate, Genotoxicity of synthetic amorphous silica nanoparticles in rats following short-term exposure. Part 2: intratracheal instillation and intravenous injection, Environ Mol Mutagen, 56 (2015) 228-244.

[12] A. Tarantini, S. Huet, G. Jarry, R. Lanceleur, M. Poul, A. Tavares, N. Vital, H. Louro, M. Joao Silva, V. Fessard, Genotoxicity of synthetic amorphous silica nanoparticles in rats following short-term exposure. Part 1: oral route, Environ Mol Mutagen, 56 (2015) 218-227.

[13] F. Pott, M. Roller, Carcinogenicity study with nineteen granular dusts in rats, Eur J Oncol, 10 (2005) 249-281.

[14] C. Uboldi, G. Giudetti, F. Broggi, D. Gilliland, J. Ponti, F. Rossi, Amorphous silica nanoparticles do not induce cytotoxicity, cell transformation or genotoxicity in Balb/3T3 mouse fibroblasts, Mutat Res, 745 (2012) 11-20.

[15] OECD, Guidance Document On the In Vitro Bhas 42 Cell Transformation Assay Series on Testing \& Assessment No. 231, ENV/JM/MONO(2016)1, OECD Publishing, Paris, (2016) 1-34.

[16] K. Sasaki, M. Umeda, A. Sakai, S. Yamazaki, N. Tanaka, Transformation assay in Bhas 42 cells: a model using initiated cells to study mechanisms of carcinogenesis and predict carcinogenic potential of chemicals, J Environ Sci Health C Environ Carcinog Ecotoxicol Rev, 33 (2015) 1-35.

[17] Z. Elias, O. Poirot, I. Fenoglio, M. Ghiazza, M.C. Daniere, F. Terzetti, C. Darne, C. Coulais, I. Matekovits, B. Fubini, Surface reactivity, cytotoxic, and morphological transforming effects of diatomaceous Earth products in Syrian hamster embryo cells, Toxicol Sci, 91 (2006) 510-520.

[18] C. Darne, C. Coulais, F. Terzetti, C. Fontana, S. Binet, L. Gate, Y. Guichard, In vitro comet and micronucleus assays do not predict morphological transforming effects of silica particles in Syrian Hamster Embryo cells, Mutat Res Genet Toxicol Environ Mutagen, 796 (2016) 23-33. 
[19] K. Rasmussen, A. Mech, J. Mast, P.J. De Temmerman, E. Van Doren, N. Waegeneers, F. Van Steen, J.C. Pizzolon, L. De Temmerman, K.A. Jensen, Synthetic amorphous silicon dioxide (NM-200, NM-201, NM-202, NM-203, NM-204). Characterisation and physico-chemical properties. JRC repository: NM-series of representative manufactured banomaterials. , Luxembourg: Publications Office of the European Union. , ( 2013) 200 p.

[20] K. Sasaki, H. Mizusawa, M. Ishidate, Isolation and characterization of ras-transfected BALB/3T3 clone showing morphological transformation by 12-0-tetradecanoyl-phorbol-13-acetate, Jpn J Cancer Res, 79 (1988) 921-930.

[21] A. Sakai, K. Sasaki, D. Muramatsu, S. Arai, N. Endou, S. Kuroda, K. Hayashi, Y.M. Lim, S. Yamazaki, M. Umeda, N. Tanaka, A Bhas 42 cell transformation assay on 98 chemicals: the characteristics and performance for the prediction of chemical carcinogenicity, Mutat Res, 702 (2010) 100-122.

[22] A. Sakai, K. Sasaki, K. Hayashi, D. Muramatsu, S. Arai, N. Endou, S. Kuroda, A. Poth, S. Bohnenberger, T. Kunkelmann, M. Asakura, H. Hirose, N. Ishii, F. Mizuhashi, S. Kasamoto, M. Nagai, K. Pant, S.W. Bruce, J.E. Sly, S. Yamazaki, M. Umeda, N. Tanaka, An international validation study of a Bhas 42 cell transformation assay for the prediction of chemical carcinogenicity, Mutat Res, 725 (2011) 57-77.

[23] IARC, Arsenic, Metals, Fibres and Dusts, IARC Monographs on the Evaluation of Carcinogenic Risks to Humans, $100 \mathrm{C}$ (2012) 1-501.

[24] S. Oh, B. Kim, H. Kim, Comparison of Nanoparticle Exposures Between Fumed and Sol-gel Nanosilica Manufacturing Facilities, Industrial Health, 52 (2014) 190-198.

[25] B. Kim, H. Kim, I.J. Yu, Assessment of Nanoparticle Exposure in Nanosilica Handling Process: Including Characteristics of Nanoparticles Leaking from a Vacuum Cleaner, Industrial Health, 52 (2014) 152-162.

[26] S. Murugadoss, D. Lison, L. Godderis, S. Van Den Brule, J. Mast, F. Brassinne, N. Sebaihi, P.H. Hoet, Toxicology of silica nanoparticles: an update, Archives of Toxicology, (2017). 